\title{
Gugon Tuhon Table Manners as a Medium of
}

\section{Cross-Generation Cultural Transfer}

\author{
$1^{\text {st }}$ Rr. Ratna Budi Andari \\ Regional Literature Study Program for \\ Javanese Literature, Faculty of \\ Humanities, \\ Universitas Indonesia, \\ Depok, Indonesia \\ rr.ratna51@ui.ac.id
}

\author{
$2^{\text {nd }}$ Widhyasmaramurti* \\ Linguistics Department, Faculty of \\ Humanities, \\ Universitas Indonesia, \\ Depok, Indonesia \\ widhyasmaramurti.s@ui.ac.id
}

\begin{abstract}
Gugon tuhon is a teaching on behaviors built upon the local wisdom of the Javanese culture. Gugon tuhon is expressed orally through prohibitions, instructions, and advice. In general, gugon tuhon is communicated by mothers to their children [1], meaning that mothers have a role in crossgeneration cultural transfers. In today's era of globalization, mothers with modern mindsets have difficulty understanding gugon tuhon. This condition reveals a problem regarding how mothers understand and use gugon tuhon as a medium for cross-generation cultural transfers, especially in the environment of Soko Village, Purworejo, Central Java. The objective of this research is to show the connection between mothers' understanding and the cultural transfer from mothers to their children. This research utilizes data on gugon tuhon table manners obtained from www.sastra.org and the book Ngengrengan Kasusastran Djawa I [2]. A qualitative descriptive method was employed by interviewing mothers with children of elementary school age. The results of the interview were analyzed using Austin's speech act theory [3] and Van Peursen's cultural development theory [4]. The findings indicate that mothers have a low level of comprehension, so cultural transfer has not been maximized yet. Moreover, the teachings on behavior in gugon tuhon are linked with educational issues, several of which exist in Indonesia, mainly about formal education in schools. However, non-formal education in the family environment also needs attention because mothers play an important role in shaping new generations of smart, polite, and cultured individuals. Therefore, this research supports the improvement of education (both formal and informal), particularly in shaping the character of children through cultural transfers.
\end{abstract}

Keywords-Javanese, gugon tuhon, table manners, mother, Purworejo

\section{Introduction}

Indonesia, a country with diverse ethnic groups, is rich with local pearls of wisdom, including those from the Javanese culture. Local wisdom is ingenuity based on life experiences produced by a certain community, so the local wisdom of the Javanese culture can only be produced by Javanese society, not by any other tribes [5]. In the past, Javanese society generally taught morals and politeness to their children using speech built upon the local wisdom of the Javanese culture, one of which includes prohibitions accompanied by fearful threats. Such speech is known as gugon tuhon. In his book Baoesastra Djawa, Poerwadarminta [6] explains that gugon tuhon means ngandel marang prakara sing dianggep duwe kadayan ngungkuli kodrat, mangka sanyatane ora ("A belief in matters that are regarded as having power surpassing God's destiny, when the truth is they do not"). According to this definition, it can be inferred that gugon tuhon is a belief.

However, the gugon tuhon concept extends beyond mere belief. Gugon tuhon also consists of meaning or teaching values. Teaching in gugon tuhon is generally delivered by parents, mainly mothers. Khoirunnisa and B. Kushartanti [1] stated that mothers have become the purveyors of gugon tuhon. Hence, they play an important role in cross-generation cultural transfers. In today's era of globalization, mothers with modern mindsets have difficulty understanding the meaning of gugon tuhon. This condition has brought about some problems, including 1) how mothers understand gugon tuhon and 2) how mothers use gugon tuhon as a medium for cross-generation cultural transfers. This research aims to shed light on the relationship between the understanding of mothers and their role in cultural transfers through gugon tuhon toward their children. If mothers understand the meaning of gugon tuhon, there is a possibility that they will deliver gugon tuhon to their children for the sake of cultural transfer. In contrast, if mothers do not understand the meaning of gugon tuhon, they will be less likely to deliver gugon tuhon to their children, which means that a cultural transfer will fail to take place.

The gugon tuhon data used in this research consist of 10 gugon tuhon related to table manners. These gugon tuhon were obtained from a site that documents Javanese scripts, www.sastra.org, which is managed by Yayasan Sastra Lestari, as well as a book written by Padmosoekotjo [2] with the observation technique employed here. The technique in this study entailed searching Serat Gugon Tuhon Prawira Winarsa, which is at www.sastra.org, and gugon tuhon in the book Ngengrengan Kasusastran Djawa I [2]. After the data were collected, they were sorted, and those linked with table manners were selected. The data on table manners from the website and the books mentioned were later used as a reference for the interviews conducted in Soko Village, Purworejo Regency. Soko Village consists of five smaller villages: Soko Krajan Village, Soko Mojo Sanga Village, Soko Kebo Kuning 1 Village, Soko Kebo Kuning 2 Village, and Soko Legok Village.

Ida Erviana and Dwi Puspitorini [10], Perkasa Mega Dwiguna and Widhyasmaramurti [11], and Khoirunnisa Kusuma and Bernadette Kushartanti conducted research on gugon tuhon table manners in 2017. These researchers all used the same method-a qualitative method-and 
approached gugon tuhon from the same perspective, namely that of children. These studies were conducted in three different locations: Kediri City, Wates, and Jombang. The current study aims to fill a gap in the literature by investigating the gugon tuhon table manners in Soko Village, which previous studies did not address. Specifically, this study focuses on the perspective of the mothers as the purveyors of cross-generation cultural transfers through gugon tuhon. Three elements distinguish this research from previous studies, which are 1) the qualitative methodology; 2) the respondents who are mothers as the purveyors of cross-generation cultural transfers through gugon tuhon; and 3 ) the research location in Soko Village, Purworejo. The respondents included 14 mothers ranging from 28 to 53 years of age with children of elementary school age.

\section{Methodology}

To elicit the perspectives of all 14 mothers, a qualitative descriptive method was used to conduct interviews. As mentioned by Sulistyo [7], the qualitative method is used in studies related to the perceptions and opinions of participants, which cannot be measured with numbers. Therefore, the qualitative descriptive method in this research was employed to describe the gugon tuhon phenomenon in Soko Village based on the mothers' perspective. Data were collected by conducting observations focused on gugon tuhon table manners from Serat Gugon Tuhon Prawira Winarsa and the book Ngengrengan Kasusastran Djawa I. In total, 10 gugon tuhon table manners were identified, which are listed below.

1. Aja sok mangan ana paturon, mundhak lara gudhigen ("Do not eat on the bed; you'll suffer from skin disease.").

2. Aja memangan karo taturon, mundhak adoh malaekate ("Do not eat while lying down; the angels might stay away from you.").

3. Aja sok mangan nyongga ajang, pincuk, takir, godhong lan sejene, mundhak kemaga ("Do not eat while propping up your plate or banana leaf; otherwise; it will be upset.").

4. Yen nengah-nengahi madhang aja sok ngombe, iku dibasakake anggedhekake kamukten ("While eating, do not drink frequently; it signifies the growth of supernatural powers.")

5. Yen madhang aja sok nisa, mundhak mati pitik ("Do not leave leftovers, or the chicken will die.").

6. Yen nengahi mamah, nanedha aja cecaturan. Mundhak keselak ("Do not speak while chewing; you could choke.").

7. Aja sok ngokop kokohan, mundhak peteng atine ("Do not eat soup straight from its plate; your heart could turn dark.").

8. Aja sok mangan pepanganan kang panas-panas, mundhak gelis ompong ("Do not eat hot food too often; your teeth will quickly deteriorate.").

9. Aja mangan karo ngadeg, wetenge dadi dawa ("Do not eat while standing up; your stomach could be elongated.").

10. Nak madhang aja ngolah-ngalih panggonan, besuk mundhak kerep rabi ("Do not eat while moving around; you will end up getting married multiple times.").
These 10 gugon tuhon were collected from different sources. Numbers (1)-(8) and (10) appear in Serat Gugon Tuhon Prawira Winarsa [13], while gugon tuhon number (9) was taken from the book Ngengrengan Kasusastran Djawa I. The meaning of each gugon tuhon was derived based on a translation from Javanese to Indonesian using the Complete Javanese-Indonesian Dictionary (Utomo, 2009) [12].

Subsequently, after obtaining data on 10 gugon tuhon about table manners, interviews with 14 mothers were conducted, resulting in the data presented in Table 1.

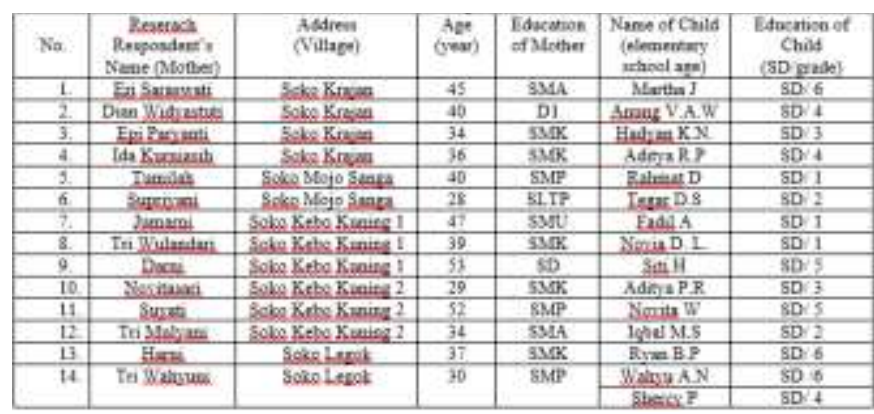

Table 1. Data on the Research Respondents

The 14 respondents received questions about 10 gugon tuhon table manners. The aim was to reveal how gugon tuhon table manners are understood and used by mothers as a medium for cross-generation cultural transfers in the Javanese community of Soko Village. Later, the interview results were analyzed using a pragmatic approach, meaning that the situation of the speech is also considered. The pragmatic theory used in this research is Austin's speech act theory [3]. Austin categorized speech acts into three types: locutionary, illocutionary, and perlocutionary acts.

A locutionary act is an act of speaking that has certain references, as mentioned by Austin [3]: "uttering a certain sentence with a certain sense and reference." An illocutionary act is the meaning of a speaker's speech, or according to Austin [3], "utterances which have a certain (conventional) force." Meanwhile, a perlocutionary act is the effect received after speaking, namely "what we bring about or achieve by saying something" [3].

In this research, a locutionary act is a gugon tuhon that is spoken by mothers to their children to explain a prohibition. An illocutionary act is the meaning conveyed by a gugon tuhon, utilized to show mothers' understanding of gugon tuhon. Meanwhile, a perlocutionary act serves to explain how mothers employ gugon tuhon as a medium for crossgeneration cultural transfers to their children. Since the respondents were mothers, the explanation of perlocutionary acts was placed not on the responses of the children but on those of the mothers as speech partners who had observed locutionary acts (gugon tuhon) from their simbah ("grandmothers"). If teaching gugon tuhon is seen as being hereditary-which began when the simbah ("grandmothers") said the gugon tuhon to their daughters (the mothers in this study) - then mothers have the main role in this cultural transfer. 
Other than Austin's theory, Van Peursen's cultural development theory [4] also supports the analysis in this research. Van Peursen divided cultural development into three steps: mythic, ontological, and functional. In the first step, the mythic step, humans have an ancient mindset and believe in supernatural elements around them. In this step, gugon tuhon is seen as a belief. In the second step, the ontological step, humans start to think that the supernatural realm contains some sort of basic knowledge. In this step, gugon tuhon develops from a belief to a form of knowledge. In the third step, the functional step, humans begin to apply knowledge to their lives as guidance. In this step, gugon tuhon is a product of culture, internalized in the cultural values of the society [8]. In this research, Van Peursen's theory was used to show the cultural transfer that occurs when mothers employ gugon tuhon table manners as a medium for cultural transfer. This cultural transfer functions to instill politeness in children, especially when they are eating.

\section{Results and Discussion}

\section{A. A Mother's Understanding of the Gugon Tuhon Table Manners}

Mothers' understanding of gugon tuhon shows how they convey gugon tuhon or transfer culture to their children. This cultural transfer functions to instill politeness in children, particularly when they are eating, which of course, is not merely expressed. Nevertheless, it is important to express the meaning or knowledge from gugon tuhon. Thus, the success of cultural transfer through gugon tuhon from mothers to their children depends on the mothers' comprehension of gugon tuhon. Below is an example of a gugon tuhon that was analyzed using Austin's theory:

(1) Aja sok mangan ana paturon, mundhak lara gudhigen

("Do not eat on the bed, or you'll suffer from skin disease.").

The locutionary act is using the gugon tuhon (1) above. This particular saying is a prohibition because it contains the word aja ("do not").

The illocutionary act, or the meaning of gugon tuhon (1), is a prohibition against having a meal on the bed since it is not the proper place to do so. Aside from violating table manners in the Javanese culture, this action also risks food being scattered on the bed, which could cause the skin to itch. The significance of this saying is explained based on the respondents' interpretations. Understanding the intention of gugon tuhon implies that the mothers comprehended the true definition of this concept not just because they knew about it or believed in it. Mothers were considered to understand gugon tuhon if their perceptions were similar to those of the researchers.

The perlocutionary act of gugon tuhon (1) is how mothers convey this speech with the intention of preventing their children from eating on the bed. Mothers inform their children that the proper place to have a meal is at the dining table and not on the bed. Based on the interviews, three mothers condoned cultural transfer using gugon tuhon (1), meaning that they acted as the perpetrators of this perlocutionary act.
The number of participants who reported carrying out this perlocutionary act in this interview proves that gugon tuhon speech exists in Soko Village. In this case, it is concerned with the use of gugon tuhon as a medium of cultural transfer from one generation to another by mothers in Soko Village. Based on the interviews, the mothers teach this speech to their children for the purpose of cultural transfer-not because they understand it but also because they are afraid it will not be passed on.

\section{B. Cross-Generation Cultural Transfer}

Cultural transfer from one generation to another is associated with mothers' knowledge and interpretations regarding the gugon tuhon speech itself. In general, if mothers perceive and understand the connotation of this speech, then it can be expected that they will pass it on as well. Nevertheless, this general view does not apply to the findings in Soko Village. In the interviews, most of the mothers stated that they still passed on this knowledge due to their fear of not relaying it to their children regardless of their ability to comprehend gugon tuhon.

The teaching of gugon tuhon speech by mothers is useful for instilling politeness in their children, especially regarding table manners, through cultural transfer, also known as cultural education. This idea is supported by Isnanda's explanation [9] in a journal article entitled "The Role of Literature and Cultural Education in Character Building for Elementary Students" that character establishment and introduction to cultural wisdom through cultural education can begin from an early age (elementary school age). Table 2 below explains the cultural transfer by mothers through gugon tuhon table manners.

\begin{tabular}{|c|c|c|c|c|c|c|c|c|c|c|c|c|c|c|c|c|}
\hline \multirow{3}{*}{$\mathrm{No}$} & \multirow{3}{*}{ Grans aban Tabie Marner } & \multicolumn{15}{|c|}{ 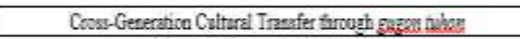 } \\
\hline & & \multicolumn{15}{|c|}{ Resercil Respondents (Motoes) } \\
\hline & & $t$ & 2 & 3 & 4 & 5 & 6 & 7 & 13 & 9 & 10 & $\mathrm{t}$ & & 12 & 13 & $1-$ \\
\hline 1. & Jhrgan axs pattans & & & & & & Z & & I & & & & & & & I \\
\hline 2. & 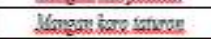 & & & & & & Z & & I & & & & & D & & \\
\hline 3. & 3hangan wangegs & & & & & & & & I & & & & & & & D \\
\hline 4. & 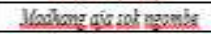 & - & - & - & - & - & - & - & - & - & - & & & - & - & - \\
\hline 5. & Harkang giv sot risa & & & ] & & & 7 & 口 & D & & & & & D & & $\bar{\square}$ \\
\hline 6. & 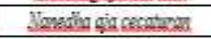 & & & a & & & I & a & D & & & & & D & & D \\
\hline 7 . & 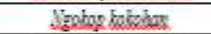 & - & - & - & - & - & - & - & - & - & - & & - & - & - & - \\
\hline 8. & Yugur hasg nux & & & & & & & I & & & & & & & & \\
\hline 9. & 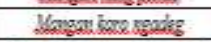 & & & & & & Z & D & I & & & & & D & & \\
\hline 10. & 3tolbong ais agolatergats & & & & & & & I & I & & & & & D & & \\
\hline
\end{tabular}

Table 2. Cross-Generation Cultural Transfer

Table 2 indicates that, among 14 mothers, only six performed a cross-generation cultural transfer using the medium of gugon tuhon. The six mothers claimed that they had heard of and were used to this speech since it was constantly recounted by their parents; as a result, they acted similarly when teaching their children. They also reported conveying these ideas during dinner in the evenings with their children. Moreover, some of the mothers communicated the speech to correct the mistakes their children made when eating. The majority of the mothers stated that their children responded in a rather positive manner, as they were able to obey and implement these table manners.

From the interviews, the six mothers hoped that their children would be able to learn, comprehend, and become accustomed to the proper eating etiquette from a young age. 
Furthermore, the mothers also expected that, through gugon tuhon, children might also develop a sense of responsibility, especially with food, such as always finishing their food. The six mothers also believed that this speech is effective enough to be used as a medium of cultural transfer to teach table manners, as well as to encourage courtesy during meals. They argued that delivering gugon tuhon in an accurate and faithful manner can increase the effectiveness of its usage.

Table 2 also indicates that, out of 10 sayings, the most effective are numbers (5) and (6) since both were uttered by six mothers. Meanwhile, numbers (4) and (7) are considered to be passive because none of the six mothers employed these gugon tuhon sayings.

According to Van Peursen's theory, the transgenerational cultural transfer by the six mothers using 10 gugon tuhon table manners is considered to be in the functional phase, as gugon tuhon is not only regarded as a belief containing basic knowledge but also as a form of knowledge taught by mothers as a way to internalize cultural values of courtesy in children.

According to Table 1, out of six mothers who conducted a cultural transfer, two of them had attended middle school, whereas four of them had a vocational/high school education. Out of the eight mothers who did not carry out a cultural transfer, the lowest educational background was elementary school, and the highest was a diploma. The average of the mothers, who implemented a total of 28 gugon tuhon as a means of cultural transfer, if divided by 10 sayings, was 2.8 (gugon tuhon). With a range from 0 to 10 ( 0 and 10 representing the lowest and highest functionality levels, respectively), 2.8 is regarded as being in the low functionality spectrum. This finding indicates that the participants did not fully use gugon tuhon speech to instill the cultural values of courtesy in children by means of a cultural transfer. Environmental factors within the family and internal factors within the mother may play a role in this problem. The environmental factors in the family refer to the lack of inheritance from simbah ("grandmothers") regarding such speech, whereas the internal factors within the mother relate to the mothers' perceptions of the speech, which could hinder the cultural transfer. Therefore, as a suggestion, it would be better if mothers would continue to convey gugon tuhon along with a clear definition to their children. If children have already been made aware of this concept, they would surely understand that they are expected to continue passing down gugon tuhon to subsequent generations. Furthermore, this strategy might also encourage mothers to include gugon tuhon knowledge as a pearl of cultural wisdom in the Javanese culture into children's education from an early age, both in the family and school environments.

Now, in the modern world with increasingly sophisticated technology, Indonesia continues to strive to be a better country. However, despite this development process, the country has not escaped various issues that need to be addressed, one of them being education, especially in formal settings such as schools. Nonetheless, non-formal education, which may happen through families, also deserves attention because families play a crucial role in educating the young, who will build Indonesia's future. To create an intelligent and cultured generation with character, parents - especially mothers - need to properly educate them. Consequently, this research serves to support improvements in education, specifically by establishing children's character through cultural transfers.

\section{Conclusion}

Based on the findings and discussions presented in this paper, it could be concluded that the mothers' understanding of gugon tuhon was related to its usage in their everyday lives. In this case, the use of such speech indicates that the mothers heard, understood, and even used gugon tuhon. However, considering that only six mothers in Soko Village still conveyed this information to their children, it could be concluded that the cultural transfer was still very minimal, implying that their perception of gugon tuhon's meaning was also low. The mothers who did not perform cultural transfers had diverse educational backgrounds, from elementary school to high school, suggesting that educational background did not affect the cultural transfer across generations. Only six mothers communicated gugon tuhon to internalize table manners within children because they were able to grasp the meaning of the sayings from their parents. These mothers played an active role in transferring their culture from one generation to another. Mothers, who often carried out this cultural transfer by introducing the definition of gugon tuhon to their children from an early age actively through daily conversation, were expected to encourage courtesy in their children. Even so, limitations of cultural transfer through gugon tuhon from mothers to their children today still exist, as observed in Soko Village as a result of the limited knowledge that the mothers possessed. Thus, gugon tuhon may cease to exist in Soko Village in the future.

Considering that the focus of this research was placed on mothers' perceptions and their delivery or cultural transfers through speech, further research is needed to understand this phenomenon from the perspectives of both mothers and children. This combination of mothers' and children's views could enrich and develop the research on gugon tuhon.

\section{Closing}

The researchers would like to thank all the respondents (14 mothers from Soko Village). The researchers would also like to extend their gratitude to Mr. Manneke Budiman, $\mathrm{PhD}$, for his input when this paper was presented during the International Young Scholars Symposium on Humanities and Arts 4.0, which was held at the Faculty of Humanities on July $24^{\text {th }}, 2019$. He provided input on the findings of this study, pointing out that, as the world becomes more modern, people are less aware of their own Javanese culture. This change threatens the existence of gugon tuhon as a part of the Javanese culture. Therefore, he suggested that mothers in Soko Village should be educated regarding the logical definition of gugon tuhon so that it is no longer applied simply because it is forced on people (or considered as something fearsome if not applied). Another strategy could be to appeal to mothers about the importance of gugon tuhon's existence as an aspect of cultural heritage that needs to be preserved. Education may also be the solution to this problem through the implementation of this concept in the 
form of roleplaying or continuous application within day-today activities, such as meals, so that the difference of its meaning before and after it is taught can be compared and contrasted.

\section{References}

[1] Khoirunnisa Kusuma, Bernadette Kushartanti. (2017). "Gugon Tuhon dalam Pandangan Anak Usia Sekolah di Jombang (Gugon Tuhon in the Perspective of School Age Children in Jombang)" in the proceeding of International Young Scholars Symposium on Humanities and Arts 2017.

[2] Padmosoekotjo. (1958). Ngengrengan Kasusastran Djawa I. Yogyakarta: Hien Hoo Sing.

[3] Austin, J.L. (1984). How to Do Things with Words. Oxford: Oxford University Press.

[4] Peursen, C.A. van. (1976). Strategi Kebudayaan (Cultural Strategy). Yogyakarta: Penerbit Kanisius.

[5] Rahyono, F.X. (2015). Kearifan Budaya dalam Kata (Cultural Wisdom in Words). Jakarta: Wedatama Widya Sastra.

[6] Poerwadarminta, W.J.S. (1939). Baoesastra Djawa. Groningen, Batavia: J.B. Wolters Uitgevers Maatschappij N.V.
[7] Sulistyo Basuki. (2010). Metode Penelitian (Research Methods). Jakarta: Penaku

[8] Ashif Az Zafi. (2017). "Transformasi Budaya Melalui Lembaga Pendidikan (Cultural Transformation Through Educational Institutions)" in LP3M Journal, Universitas Sarjanawiyata Tamansiswa Yogyakarta.

[9] Isnanda, Romi. (2015). "Peran Pengajaran Sastra dan Budaya dalam Pembentukan Karakter Siswa Sekolah Dasar (The Role of Literature and Culture in Character Building for Elementary School Students )" in Gramatika Journal, STKIP PGRI Western Sumatra.

[10] Ida Erviana and Dwi Puspitorini (2017). "Pengaruh Usia Terhadap Pemahaman Anak tentang Gugon Tuhon Adab Makan: Studi Kasus Siswa Sekolah Dasar di Kota Kediri (Age Influences on Children's Understanding of Gugon Tuhon Adab Makan: Case Study of Elementary School Students in Kediri )" (Essay, Universitas Indonesia).

[11] Perkasa Mega Dwiguna, Widhyasmaramurti. (2017). "Pengaruh Usia pada Pemahaman Anak terhadap Larangan dalam Gugon Tuhon (Age Influences on Children's Understanding of Prohibitions in Gugon Tuhon)" in the proceeding of International Young Scholars Symposium on Humanities and Arts 2017.

[12] Utomo, Sutrisno Sastro. (2009). Kamus Lengkap Jawa-Indonesia (Javanese-Indonesian Dictionary). Yogyakarta: Penerbit Kanisius.

[13] Yayasan Sastra Lestari. "Serat Gugon Tuhon Prawira Winarsa" in https://www.sastra.org/ Accessed on 20 March 2019, 10:31 p.m WIB 